\title{
ФЕДЕРАЦИЯ - ОДНА ИЗ ФОРМ ГОСУДАРСТВЕННОГО УСТРОЙСТВА
}

\section{FEDERATION IS A FORM OF GOVERNMENT}

J. Bozieva

Summary. The article analyzes federalism as a political and legal phenomenon, the beginning of its construction, the relationship of the concepts of "Federation" and "federalism", the main properties of modern democratic state federalism (Federation).

Keywords: federalism, Federation, properties and principles of federalism, democracy.

\author{
Бозиева Юлия Геннадьевна \\ К.ю.н., дочент, Кабардино-Балкарский \\ государственный аграрный университет \\ им. В.М. Кокова (г. Нальчик) \\ Nezabudka7557@yandex.com
}

Аннотация. В статье анализируется федерализм как политико-правовое явление, начала его построения, рассматривается соотношение понятий «федерация» и «федерализм», главные свойства современного демократического государственного федерализма (федерации).

Ключевые слова: федерализм, федерация, свойства и принципы федерализма, демократия.

зависит от властных полномочий общефедеральных государственных органов. Федерация характеризуется значительным ограничением государственного суверенитета субъектов федерации и самого союза [3]. Члены федерации - соучастники общегосударственного суверенитета - фактически не обладают индивидуальным суверенитетом и правом одностороннего выхода (сецессии) из союзного государства.

Федерация характеризуется наличием двух систем законодательной, исполнительной и судебной власти: федеральной и субъектов федерации.

Субъекты федерации, как правило, обладают правом принятия собственных конституций, но с условием приоритета союзной конституции. Международная деятельность субъектов федерации ограничена. Управление вооруженными силами в пределах федерации непосредственно осуществляется союзными государственными органами. Субъектам федерации запрещается в мирное время создавать профессиональные вооруженные формирования [4].

Определяющие решения принимаются центральными высшими органами власти с участием субъектов федерации. В большинстве федераций существуют единое союзное гражданство и гражданство субъектов федерации.

В федерации используется двухканальная система налогов: федеральные налоги и налоги субъекта федерации. Как правило, собранные налоги поступают в общефедеральную казну и затем уже часть их (посредством бюджета) передается для использования субъектами федерации. Иной порядок может существенно подры- 
вать федеративную природу государства, угрожать его целостности.

Главным вопросом любой Федерации является разграничение компетенции между союзом и субъектами федерации. От решения этого вопроса зависят юридическое положение государственных образований и характер тех отношений, которые складываются между федерацией и ее членами [5]. Как правило, эти отношения в самом основном определяются конституцией федерации или федеральными договорами. Поэтому в федерации реализуется либо конституционный, либо договорно-конституционный принцип.

Конституции федеративных государств за редким исключением (бывший СССР) не предоставляют субъектам федерации право выхода из нее. Во время «перестройки» в СССР это право было использовано сначала тремя прибалтийскими республиками - Литвой, Латвией, Эстонией. Затем из состава СССР вышли Россия, Белоруссия и Украина, что привело к его окончательному распаду.

Попытки самовольного выхода из федераций мирным или вооруженным путем, за редким исключением (Сингапур из Малайзии в 1965 г., Бангладеш из Пакистана) пересекаются в других федерациях.

В начале XX в. различные партии в России и их теоретики высказывали свое отношение к федерализму. Консервативные партии были против государственного федерализма, радикальные признавали ее. Например, радикальная партия выступала за Соединенные Российские Штаты; социалисты-революционеры предусматривали в своей программе «возможно более широкое применение федеративного начала к отношениям между национальностями» [7].

Однако теория федерализма продолжает развиваться. Многие авторы считают, что в США в 30-40-е годы XX в. на место «дуалистическому федерализму» пришел «кооперативный федерализм».

Существенный вклад в теорию федерализма внес Д. Элейзер. Скептически относясь к теориям федерализма, изложенным в статье Э. Корвина «Конец двойного федерализма», Д.Элейзер выделяет несколько подвидов федерализма. Первый из них - федерация, представляет собой форму организации государственной власти, главные принципы которой были сформулированы отцами-основателями США в конституции 1787 года. Второй подвид федерализма, по мнению Д. Элейзера,конфедерация - был общепризнанной формой федерализма до 1787 г. Третий подвид - федератизм. Именно таким образом построены взаимоотношения США с Пуэрто-Рико и Гуамом. Четвертый подвид - ассоциированная государственность. Подобного рода взаимоотношения установлены между США, с одной стороны, и федерированными штатами «Микронезии» и Маршалловыми островами - с другой.

В программе РСДРП в начале признавалось право на широкую автономию и самоопределение в рамках унитарного государства, а позже и федеративное устройство. После Октябрьской революции В.И. Ленин также стал активно выступать за федеративное устройство России. В программе РКП(б) 1919 г. предусматривалось, что одной из переходных форм на пути к полному единству народов является федеративное объединение государств, организованных по советскому типу. Х съезд РКП(б) 1921 г. подтвердил «целесообразность, гибкость федерации как общей формы государственного союза советских республик».

Россия и практически пыталась освоить федеративное устройство «на основе свободного союза свободных наций как федерации советских национальных республик», которое было декларировано в конституции 1918 г., а также в «Декларации прав трудящегося и эксплуатируемого народа» (январь 1918 г.), а позже закреплено в Конституции СССР 1924 г. после одобрения первым съездом Советов (1922 г.) проекта Декларации и Договора об образовании СССР и вступления его в силу 31 декабря 1922 г.

Федеративная организация Союза определялась и действием своего рода геополитического фактора целью создания мировой советской республики.

В период создания многонационального СССР в теории вновь встал вопрос о делимости суверенитета. Победу одержала (в значительной мере в силу объективных обстоятельств) доктрина двойного суверенитета. По Конституции СССР 1924 г. субъекты Союза объявлялись суверенными государствами с правом выхода из него. И хотя в реальности эта декларация не соответствовала действительному положению республик в Союзе, мало отличающемся от унитарного государства, свою разрушительную роль в перспективе она сыграла в кризисной ситуации конца $80-x-$ начала $90-x$ годов.

Эта проблема вновь возникла при формировании федеративного устройства России и снова в кризисной ситуации, как и в начале века, когда выбор и время были ограничены. В статье 65 Конституции России 1993 г., созданной поспешно, в числе 85 субъектов федерации перечисляется 22 республики (бывшие автономные республики и автономные области (ССР). В статьях 4 и 5 отмечается, что республика (государство) имеет свою Конституцию и законодательство; суверенитет Российской 
Федерации распространяется на всю ее территорию [11]. Конституция России и федеральные законы имеют верховенство на всей территории Российской Федерации. Статус республики определяется Конституцией России и конституцией республики (ст. 66).

Федерация - продукт длительной эволюции государств. Истоки федерации обнаруживаются в далеком прошлом, в истории племенных союзов и союзов государств.

Исторически федерация для таких стран, как США, Швейцария, Германия, была формой преодоления политической раздробленности. В частности, федерация имеет глубокие корни в истории Германии.

Германские конфедеративные союзы возникли под внешним воздействием - наполеоновской Франции в 1806 г. и держав-победителей в 1813 г. В 1871 г. учредительный рейхстаг (парламент) принял общеимперскую конституцию. После объединения страны кайзеровская империя официально объявила себя (согласно конституции) вечным союзом, куда в конечном итоге вошли 25 государств: 4 королевства, 6 великих герцогств, 5 герцогств, 7 княжеств, 3 вольных города (Гамбург, Бремен и Любек), а также имевшая открытый статус Эльзас-Лотарингия. Ни один из входивших в союз субъектов не мог ни выйти, ни быть изгнанным из него.

Особую роль в союзе играла Пруссия, самая обширная и доминирующая. (Пруссия составляла 55\% территории и 61\% населения империи). По Конституции 1871 г. прусский король стал императором Германской империи.

По своеобразной исторической закономерности воссоздавшая федерализм конституция ФРГ 1949 г. также была принята под влиянием держав-победителей.

Федеративное устройство ФРГ еще раз продемонстрировало свою эффективность в связи с воссоединением Германии в 1990 г. Представляется несомненным, что 16 земель объединенной Германии (11 западных и 5 образованных на территории бывшей ГДР) обладают довольно высокой степенью автономности, вплоть до участия в структурах и деятельности Европейского союза.

В настоящее время число федераций в мире сравнительно невелико - $1 / 9$ всех государств мирового сообщества, но это, как правило, крупные страны, в них проживает треть всего человечества.

Всего федеративную форму имеют 6 государств в Европе: Австрия, Бельгия, Германия, Швейцария, Россия, Югославия; 4- в Азии: Индия, Малайзия, Пакистан, ОАЭ;
4 - в Африке: Коморские острова, Нигерия, Танзания, Эфиопия; 6 - в Америке: Аргентина, Бразилия, Венесуэла, Канада, Мексика, США; 2 - в Океании: Австралия и Папуа-Новая Гвинея. В их состав входит различное число субъектов: в США - 50 штатов, в Канаде - 10 провинций, в ФРГ - 16 земель, в Швейцарии - 23 кантона. Федерациями считались бывшие СССР, Югославия и Чехословакия.

Большинство федераций построены по административно-территориальному принципу. Проживающие в них национальные, этнические группы либо разрознены и не составляют компактных групп (например, в США, Бразилии, Мексике, ФРГ), либо разделены между разными государственными образованиями внутри федерации.

Как показывает история, этнос, включенный в нацию или государственную общность, но не интегрированный в нее, может в определенный момент очнуться и начать борьбу за национальное обособление. Сегодня мы наблюдаем массовое пробуждение таких этносов в мире и особенно в постсоциалистическом пространстве.

В классических федерациях политико-территориальное деление, как правило, не привязано к национальному составу населения.

В многонациональных федеративных образованиях возникает крайне сложная проблема гармонизации не только социальных, но и этнических интересов. Особенно это актуально для таких формирующихся федераций, как Россия, Бельгия.

В последнее время в Европе и других регионах мира наряду с процессами интернационализации (экономико-политической и государственной интеграции) наблюдается тенденция государственной суверенизации наций и этнической дифференциации. Ситуации Квебека, Северной Ирландии, Севера Италии, фламандской Бельгии, Страны Басков в Испании и другие говорят нам, что процесс генезиса наций в странах, реализующих модель национального государства, явно не завершился.

Если недооценка национального фактора может привести к сепаратизму, то преувеличение национального момента в государственном строительстве может не сплотить, а напротив, подорвать государственную общность, единство федерации, как это произошло в бывшем СССР.

Практика показала, что федерации, созданные по территориальному принципу, оказались более жизнеспособными, чем федерации, созданные по национально-территориальному принципу (СССР, Югославия, 
Чехословакия). Хотя некоторые политики надеются, что противоречия между ними будут уменьшаться на основе нового понимания нации как согражданства, которое заложено в Конституции России.

В центре проблем, возникающих в теории и практике федерализма, находится вопрос разграничения компетенции между союзным государством и составляющими его союзными образованиями, в иной терминологии, делимости суверенитета между федерацией и субъектами.

В конце XIX в. германские юристы и политики столкнулись с противоречивым фактом, связанным с проблемой делимости суверенитета.

Немцы сохраняют в Конституции 1871 г. название государство и за германской империей, и за входящими в его состав королевствами. Таким образом, в теории и на практике возникает проблема двойного суверенитета. Немецким теоретикам и политикам хватило мудрости терпеть это противоречие вплоть до принятия Конституции Веймарской республики 1919 г., хотя реальное разрешение проблемы в условиях мононационального состава населения дано в конституции 1949 г., в соответствии с которой субъекты федерации-земли уже предстают не как суверенные государства, а как государственные образования с ограниченным суверенитетом, не обладающим всеми атрибутами государства.

К. Маркс и Ф.Энгельс предлагали иное решение проблемы. К. Маркс, Ф.Энгельс, а позже и В.И.Ленин до 1918 г., выступая за унитарное государство с широкой местной автономией, довольно скептически относились к идее и практике федеративного устройства современных им государств.

В тесной внутренней связи с кругом идей и настроений, порожденных революционными потрясениями в Европе, происходило освоение идей федерализма ив России. Реформистские проекты преобразований государственного устройства исходили как из правительственных кругов, так и из среды оппозиции. Один из первых планов федерализации был предложен в России Н.Н. Новосильцевым, министром юстиции при Александре I в 1818 г., который предусматривал в русле идей либерального конституционализма и принципов Польской конституции 1815 г. разделение государства на наместничества, обладающие собственными двухпалатными сеймами и значительной внутренней автономией.

Для революционных движений XIX в. и их идеологий в России были характерны несколько концепций федерации: федеративной конституционной монархии (Н.М.Муравьев), федеративной конституционной республики (П.И.Пестель), общеславянской федера- ции (декабристское «Общество соединенных славян», М.А. Бакунин в 40-х годах, Т.Г. Шевченко). Известно, что еще в XVII в. Ю. Крижанич ратовал за создание славянской федерации. О федеративной организации будущей России писали Н.Г. Чернышевский, А.П.Щапов, Н.И. Костомаров и другие. В частности, Н.И. Костомаров утверждал, что татарское завоевание затормозило развитие Руси и сделало крутой поворот в государственной жизни.

Идеи федерализма содержались в программных документах народнических организаций в России.

Определенный интерес представляют сегодня взгляды русских анархистов на проблемы федерализации. Так, М.А.Бакунин, отвергая идею государственности, взамен предлагал свой принцип федерализма: федеративную свободную организацию - «снизу вверх - индивидов, групп, общин, волостей, областей 11 народов: политическая и экономическая организация социальной жизни не должна более... исходить сверху вниз и от центра к периферии, по принципу единства и вынужденной централизации, но снизу вверх и от периферии к центру, по принципу свободной ассоциации и федерации» [9].

Одной из основных проблем федеративного устройства государства, которой уделяется большое внимание в науки, остается вопрос о суверенитете, а также распределении полномочий и предметов ведения между самой федерацией и её составными частями.

До сих пор среди ученых-теоретиков и специалистов-практиков нет единого мнения касательно этого вопроса. Часть авторов считают, что нужно исходить из того, что в федеративном государстве, как и в любом другом может быть лишь один суверенитет. Другие авторы рассматривают данный вопрос с другой стороны. Их позиция заключается в том, что суверенитет может быть разделен, и им обладает как сама федерация в целом, так и её субъекты в определенной «части».

Субъекты Российской Федерации согласно Федеральному договору от 31 марта 1992 года «О разграничении предметов ведения и полномочий между федеральными органами государственной власти Российской Федерации и органами власти суверенных республик в составе Российской Федерации» и другим Федеральным договорам о разграничении предметов ведения и полномочий, а также во многих конституциях этих субъектов, говорится о их суверенности.

Однако, это может рассматриваться только как определенная самостоятельность в пределах своих полномочий и пределов ведения. Статья 73 Конституции Россий- 
ской Федерации предоставляет субъектам Федерации «всю полноту государственной власти», кроме полномочий по предметам ведения Федерации и предметам совместного ведения Федерации и её субъектов.

Разграничения полномочий и предметов ведения между федеральным центром и субъектами, частями государства является основной нерешенной проблемой федеративного государственного устройства. Он является наиболее сложным и дискуссионным.

Традиционно под термином централизация понимается определенная система управления, при которой местная власть, лишена самостоятельности и действует по указанию из федерального центра. Термин централизация (от англ. centralization) - означает сосредоточение чего-либо в одном месте, центре или руках.

Основной задачей федерации является обеспечение эффективности осуществления функций государства, а также создание системы управления, которая была бы наиболее удобной и приближенной к людям, населению этой страны и ответственной перед ними.

От правильного разграничение и распределение полномочий зависит эффективность власти и гарантии обеспечения соблюдения прав и свобод, а также интересов граждан и верховенства права. От этого распределения зависит какую роль в жизни людей будет играть федеративное устройство государства [8]. Либо оно будет работать на развитие экономических, политических, социальных, национальных, культурных потребности населения, либо тормозить их.

В некоторых странах полномочия и исключительные предметы ведения федерации закрепляются в основном в конституции страны. Это значит, что только федерация обладает достаточными полномочиями для регулирования определенных вопросов общественной жизни людей. Хотя это не исключает возможность передачи федерацией в определенных случаях, части полномочий её субъекту.

Как правило, к исключительной компетенции федерации относятся такие вопросы как: оборона, внешняя политика, федеральные налоги, денежное и валютное обращение, инфраструктура, охрана природы и прочее. Все то, что требует руководства федеральной власти.

Изучение проблем разграничения полномочий и предметов ведения между федерации и её субъектами, связанных с децентрализацией федерации на современном этапе развития государственности является на сегодняшний момент наиболее актуальным. Так как данный вопрос затрагивает основы государства, государственного строя, основ конституции, то он требует более глубокого, детального и внимательного изучения среди учёных и специалистов, в том числе и обсуждения в обществе. Ведь незначительные изменения могут привести к улучшению или ухудшению социально - экономического развития общества, что напрямую влияет на благосостояние населения.

\section{ЛИТЕРАТУРА}

1. К Конституция Российской Федерации (принята всенародным голосованием 12.12.1993) (с учетом поправок, внесенных Законами Российской Федерации о поправках к Конституции Российской Федерации от 30.12.2008 № 6-ФКЗ, от 30.12.2008 № 7-ФК3, от 05.02.2014 № 2-ФК3, от № 11-ФКЗ) // Собрание законодательства Российской Федерации. — 04.08.2014.— № 31.—- С. 4398.

2. 0 принятии в Российскую Федерацию Республики Крым и образовании в составе Российской Федерации новых субъектов - Республики Крым и города федерального значения Севастополя: федеральный конституционный закон от 21.03.2014 № -ФКЗ // Российская газета.— № 633824.03 .2014$.

3. Болтенкова Л. Ф. Учение о федерализме и его реализация в развитии государств. — М.: Изд-во РАГС, 2014. — $260 \mathrm{C.}$

4. Городилов А.А., Губин Ю. И., Соколов А. Н. Федерализм в России — состояние, проблемы, перспективы развития.— Калининград, 2010. - 170 с.

5. Давыдова М.А., Шишпаренок 0. Н. Структурное построение конституций (уставов) субъектов Российской Федерации //Конституционное (уставное) регулирование в субъектах Российской Федерации. - Иркутск, 2007.- 294 с.

6. Карапетян Л. М. Федеративное устройство Российского государства: монография. — М.: Норма. — 2013. — 230 c.

7. Силинов П. М. Федерализм в зарубежных странах: конституционно-правовые и политические технологии. автореферат дис. ... доктора юридических наук: / Рос. акад. гос. службы при Президенте РФ.- Москва, 2005.— 51 с.

8. Умнова И. А. Конституционные основы современного Российского федерализма: автореф. дис. к.ю. н. — М.: МГЮА. — 2011. - 120 с.

9. Чиркин В. Е. Современное государство: монография.- М.: Юристъ. - 2012. - 330 с.

10. Крылова Е. Г. Федерализм как демократическая территориальная организация правового государства //Конституционное и муниципальное право.2014. - № 16. - С. 14-19.

11. Эбзеев Б. С. Российский федерализм: равноправие и асимметрия конституционного статуса субъектов //Москва. — 2013.— № 3.— С. 6-8. 